\title{
Pengaruh Pemberian Ekstrak Bawang Putih (Allium Sativum Linn) Terhadap Zona Hambat Pertumbuhan Bakteri Staphylococcus Epidermidis Secara In Vitro
}

\author{
Akbar Diosasqia Putra \\ Dosen Fakultas Kedokteran, Universitas Hang Tuah, Jl. Arief Rachman Hakim No. 150 Sukolilo, Surabaya, 60111 \\ E-mail: akbardiosasqia@gmail.com
}

\begin{abstract}
Background:Infectious diseases are the main cause of high morbidity and mortality rates, especially in developing countries such as Indonesia.Indonesia is abundant with plants that can be used as herbal medicine. Garlic is known as having antibacterial elements, one of them is for Staphylococcus epidermidis which is one cause of dermal disease. This disease is often ignored in Indonesia because the price of the drug is not affordable by the community. So that garlic should be used as an alternative medicine. Objective: This study aims to determine the antibacterial effect of garlic extract (Allium sativum $L$.) retarding the growth of Staphylococcus epidermidis. Methods: This study is experimental laboratory using plate diffusion method of "Postest Ony Control Group Design" design. There are 7 groups, 5 treatment groups and 2 control groups. The concentration of treatment group was $100 \%, 50 \%, 25 \%, 12,5 \%, 6,25 \%$ while for positive control using chloramphenicol and aquadest as negative control. The bacteria used were Staphylococcus epidermidis. Results: The results showed that garlic extract (Allium sativum L.) had an antibacterial effect in inhibiting the growth of Staphylococcus epidermidis. The inhibitory zone concentration in the statistical results shows there are significant differences with values $p=0.000$ or $p<\alpha$. Conclusion: The conclusion of the study showed that Garlic Extract (Allium sativum L.) had an antibacterial effect to retarding the growth of Staphylococcus epidermidis.
\end{abstract}

Keywords - : Staphylococcus epidermidis; garlic; antibacteria.

\section{LATAR BELAKANG}

Penyakit infeksi merupakan penyebab paling utama tingginya angka kesakitan (morbidity) dan angka kematian (mortality) terutama pada negara-negara berkembang seperti Indonesia. Penyakit infeksi merupakan suatu penyakit yang disebabkan karena adanya mikroba patogen atau bakteri. Salah satunya adalah bakteri Staphylococcus epidermidis.

Staphylococcus epidermidisadalah bakteri gram positif dengan koagulasi negatif. Sebagian besarS. Epidermidis ini adalah flora normal kulit dan membran mukosa manusia. Bakteri ini dapat berkembang menjadi agen patigen ada Infeksi nosokomial dan sepsis. Bakteri Staphylococcus epidermidis dapat membentuk biofilm yang membuat banyak antibiotik resisten terhadap bakteri ini (multidrug resistant). Timbulnya resistensi menyebabkan banyak penyakit infeksi yang gagal untuk ditanggulangi dengan obat antibiotika yang ada.

Selama ini, antibiotik menjadi pengobatan anti-infektif yang efektif. jika mikroorganisme resisten meningkat, banyak prosedur medis standarakan gagal atau menjadi sangat beresiko. Infeksi yang disebabkan oleh mikroorganisme resisten dapat mempersulit penyembuhan, peningkatan biaya pengobatan dan resiko kematian yang meningkat. Fenomena resistensi ini memaksa peneliti di dunia untuk menemukan antibiotik alternatif dari tanaman herbal.

Bawang putih (Allium sativum) telah menjadi pengobatan sejak tahun 1550 sebelum masehi. Bawang putih berpotensi sebagai pengganti antibiotik. Penggunaan dan pengaplikasian yang mudah dan dapat ditemukan di seluruh dunia menjadi keuntungan bawang putih. Bawang putih dipercaya memiliki manfaat antispasme, ekspektoran, antiseptik, bakteriostatik, antiviral, antihelmintik dan antihipertensi. Bawang putih memiliki senyawa allisin sebagai agen antibakteri terhadap bakteri gram-positif. Allisin terbentuk saat bawang putih mengalami kerusakan.

Dari latar belakang tersebut, peneliti ingin melakukan penelitian terhadap pengaruh ekstrak bawang putih (Allium sativum) untuk menguji aktivitas antimikroba terhadap pertumbuhan bakteri Staphylococcus epidermidis dengan mengetahui zona hambat bakteri secara in vitro.

\section{MATERI DAN METODE PENELITIAN}

Penelitian ini merupakan jenis penelitian eksperimental laboratoris secara in vitro. Penelitian ini menggunakan desain penelitian rancangan randomized control grouppost-test design. Variabel bebas dalam penelitian ini adalah konsentrasi ekstrak bawang putih $(100 \%, 50 \%, 25 \%, 12,5 \%, 6,25 \%)$.Sedangkan variabel terikat penelitian ini adalah zona hambat Staphylococcus epidermidis.

Sampel menggunakan isolat Staphylococcus epidermidis. Pengambilan jumlah sampel dengan metode total sampling. Berdasarkan rumus Federer, minimal sampel yang digunakan adalah 3,5 (dibulatkan 4) sehingga pengulangan dilakukan 
Website : http://agritek.unmermadiun.ac.id/index.php/agritek

sebanyak 4 kali. Jumlah sampel ditingkatkan validasinya dengan menyamakan jumlah koloni bakteri sesuai standart Mac Farland 0,5. Penelitian ini menggunakan 7 kelompok perlakuan dengan rincian:

1. Kontrol Negatif : Bakteri Staphylococcus epidermidis diberi aquadest.

2. Kontrol Positif : Bakteri Staphylococcus epidermidis diberi Chloramphenicol $30 \mu \mathrm{g}$

3. Kontrol Perlakuan : Bakteri Staphylococcus epidermidis diberi ekstrak bawang putih 6,25\%

4. Kontrol Perlakuan : Bakteri Staphylococcus epidermidis diberi ekstrak bawang putih 12,5\%

5. Kontrol Perlakuan : Bakteri Staphylococcus epidermidisdiberi ekstrak bawang putih 25\%

6. Kontrol Perlakuan : Bakteri Staphylococcus epidermidis diberi ekstrak bawang putih 50\%

7. Kontrol Perlakuan : Bakteri Staphylococcus epidermidis diberi ekstrak bawang putih $100 \%$

Pembuatan ekstrak bawang puth menggunakan bawang putih yang sudah bersih dan dikeringkan, kemudian diblender hingga berbentuk bubuk dan ditimbang beratnya sebanyak 500 gr, bubuk bawang putih direndam dalam larutan etanol $96 \%$ dan didiamkan dalam suhu ruangan selama 3x24 jam dan dilakukan pengadukan setiap hari. Campuran organic kemudian difiltrasi menggunakan vacuum filter setiap 1×24 jam. Filtrat dipisahkan dari pelarut dengan rotary evaporator pada suhu kurang dari $50^{\circ} \mathrm{C}$. Ekstrak bawang putih dibuat dalam konsentrasi 100\%, 50\%, 25\%, 12,5\%, 6,25\%.

Uji kepekaan bakteri dilakukan dengan cara difusi. Isolat bakteri Staphylococcus epidermidis diambil dan dioleskan ke permukaan agar Mueller Hinton dengan lidi kapas steril kemudian kertas cakram dicelupkan ke masing-masing larutan uji. Pada kontrol negative diberikan aquadest, pada kontrol positif diberikan Chloramphenicol $30 \mu \mathrm{g}$, dan kontrol perlakuan diberikan larutan uji ekstrak bawang putih dengan konsentrasi 100\%, 50\%, 25\%, 12,5\%, 6,25\%. Setelah kertas cakram dicelupkan, kertas cakram diambil menggunakan pinset steril dan diletakan diatas media agar, kemudian diinkubasi pada suhu $37^{\circ} \mathrm{Cselama} 24$ jam.

Pengamatan pertumbuhan bakteri dilakukan pada setiap cawan petri, kemudian zona hambat diukur menggunakan digital calipers dalam satuan millimeter. Hasil pengukuran zona hambat yang diperoleh merupakan rata-rata pengukuran dari 3 arah ukur diameter zona hambat (Harley and Prescott, 2002).

Data yang diperoleh dalam penelitian ini kemudian diolah dan dianalisa secara statistik dengan menggunakan software SPSS 23.0. uji analisa yang dilakukan yaitu uji normalitas untuk mengetahui apakah data terdistribusi normal atau tidak, uji homogenitas untuk mengetahui apakah varian sample berbeda atau tidak, apabila distribusi data normal dan varians data homogen dilakukan uji one-way ANOVA. Apabila salah satu uji normalitas dan homogenitas tidak terpenuhi dilakukan uji Kruskal Wallis untuk mengetahui pengaruh pemberian ekstrak bawang putih sebagai antibakteri terhadap bakteri Staphylococcus epidermidis. Hasil analisa disajikan dalam bentuk tabel.

\section{III.HASIL PENELITIAN}

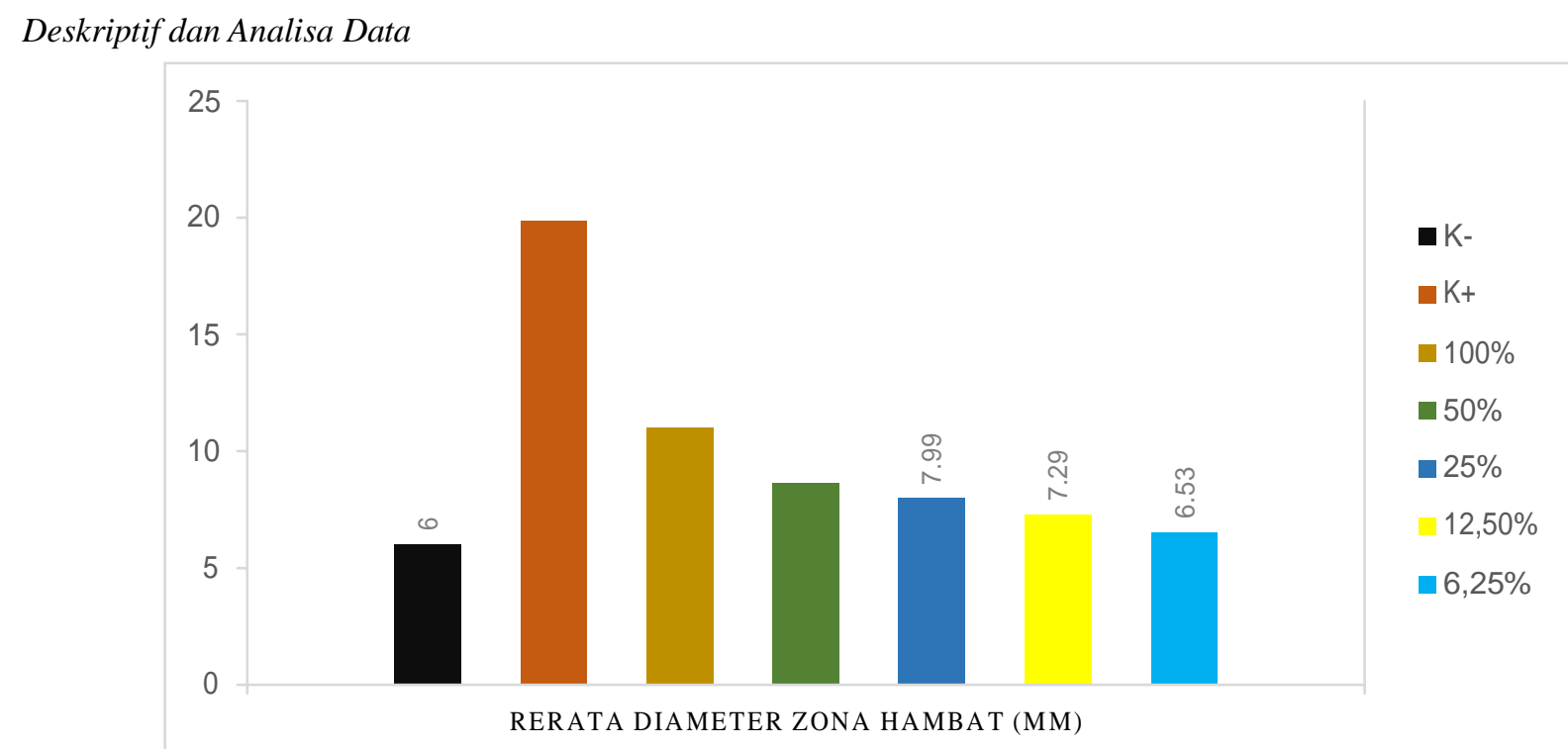

Gambar 1. Grafik rata-rata zona hambat pertumbuhan Staphylococcus epidermidis terhadapat berbagai konsentrasi ekstrak bawang putih (Allium Sativum), Chloramphhenicol, dan aquadest.

Rerata diameter zona hambat bakteri Staphylococcus epidermidis pada pemberian ekstrak bawang putih didapatkan hasil terbesar pada konsentrasi $100 \%$ dengan rerata sebesar 11,03 mm. sedangkan zona hambat paling kecil didapatkan pada ekstrak bawang putih dengan konsentrasi $6,25 \%$ dengan rerata sebesar $6,53 \mathrm{~mm}$. hal ini menunjukan bahwa kelompok sampel yang diberi ekstrak bawang putih konsentrasi $100 \%$ memiliki sifat antibakteri tertinggi dibandingkan kelompok lain yang diberi ekstrak bawang putih. Pada kontrol negative rata-rata diameter didapatkan paling rendah dari seluruh kelompok yaitu $6 \mathrm{~mm}$ dan kontrol positif memiliki rata-rata tertinggi dari seluruh kelompok penelitian yaitu 19, $86 \mathrm{~mm}$. 
Website : http://agritek.unmermadiun.ac.id/index.php/agritek

Tabel 1. Hasil Uji Komparasi Non Parametrik

\begin{tabular}{|c|c|c|c|}
\hline Kelompok & Rata-rata & $\begin{array}{c}\text { Uji Normalitas } \\
\text { Saphiro-Wilk }\end{array}$ & $\begin{array}{c}\text { Uji Non Parametrik } \\
\text { Kruskal Wallis }\end{array}$ \\
\hline Kontrol Negatif & 6 & \multirow{7}{*}{$\begin{array}{c}0.000 \\
(\mathrm{p} \text { value }>0.05)\end{array}$} & \multirow{7}{*}{$\begin{array}{c}0.000 \\
(\mathrm{p} \text { value }<0.05)\end{array}$} \\
\hline Kontrol Positif & 19,86 & & \\
\hline $100 \%$ & 11,03 & & \\
\hline $50 \%$ & $\underline{8,63}$ & & \\
\hline $25 \%$ & 7,99 & & \\
\hline $12,5 \%$ & 7,29 & & \\
\hline $6,25 \%$ & 6,53 & & \\
\hline
\end{tabular}

Data penelitian dilakukan uji normalitas menggunakan uji Shapiro-Wilk. Data dikatakan berdistribusi normal apabila nilai signifikansi lebih dari 0,05 ( $\mathrm{p}$ value $>0,05$ ). Uji normalitas menunjukan angka0.000 sehingga dapat disimpulkan bahwa data tidak terdisitrbusi normal. Karena data tidak terdistribusi normal, berikutnya dilakukan uji non parametrik Kruskal-Wallis untuk membandingkan perbedaan antara kelompok kontrolpositif (chloramphenicol), kelompok kontrol negatif (aquadest), kelompok perlakuan $(100 \%, 50 \%, 25 \%, 12,5 \%, 6,25 \%)$. Hasil yang didapat pada uji kruskal-wallis adalah 0,000 (p value < 0,05 ) hal ini menunjukkan bahwa terdapat perbedaan signifikan pada pemberian ekstrak bawang putih terhadap pertumbuhan bakteri Staphylococcus epidermidis.

Analisa data dilanjutkan dengan Uji Post Hoc menggunakan Mann-Whitney untuk membandingkan kelompok kontrol positif, kontrol negatif, dan ekstrak bawang putih dengan konsentrasi berbeda.

\begin{tabular}{|c|c|c|c|c|c|c|}
\hline & $\mathbf{K}+$ & $100 \%$ & $50 \%$ & $25 \%$ & $12,5 \%$ & $6,25 \%$ \\
\hline K- & $0,014^{*}$ & $0,014^{*}$ & $0,014 *$ & $0,014^{*}$ & $0,014^{*}$ & $0,014^{*}$ \\
\hline $\mathbf{K}+$ & & $0,021^{*}$ & $0,021^{*}$ & $0,021 *$ & $0,021^{*}$ & $0,021^{*}$ \\
\hline $100 \%$ & & & $0,021 *$ & $0,021^{*}$ & $0,021^{*}$ & $0,021^{*}$ \\
\hline $50 \%$ & & & & $0,021^{*}$ & $0,021^{*}$ & $0,021^{*}$ \\
\hline $25 \%$ & & & & & $0,021^{*}$ & $0,021^{*}$ \\
\hline $12,5 \%$ & & & & & & $0,021^{*}$ \\
\hline
\end{tabular}

*: Terdapat perbedaan bermakna / signifikan

Berdasarkan hasil uji Post-Hoc, dapat disimpulkan bahwa terdapat perbedaan bermakna diseluruh perlakuan secara statistik, dimana pada ekstrak bawang putih dengan konsentrasi $25 \%$ sudah dapat menghambat pertumbuhan bakteri meski tidak sebesar chloramphenicol.

\section{IV.DISKUSI}

Pada hasil penelitian didapatkan hasil yang berbeda dan bermakna antara chlorampenicol sebagai kontrol positif, aquadest sebagai kontrol negatif dan ekstrak bawang putih dengan berbagai konsentrasi yaitu 100\%, 50\%, 25\%, 12,5\%, 6,25\% terhadap Staphylococcus epidermidis (Tabel 1). Kloramfenikol merupakan antibakteri yang bersifat bakteriostatik. Bakteri Staphylococcus epidermidis lebih sensitif terhadap kloramfenikol. Kloramfenikol merupakan antibiotik berspektrum luas yang dapat menghambat aktifitas ribosom bakteri.

Pada konsentrasi $100 \%$ menunjukkan daya hambat paling besar daripada konsentrasi yang lainnya namun tidak melebihi dari besar kontrol positifnya yaitu chloramphenicol. Pada konsentrasi 50\%, 25\%, 12,5\%, dan 6,25\% menunjukkan daerah zona hambat yang lebih besar daripada kontrol negatifnya yaitu aquadest meski tidak sebesar chloramphenicol. 
Website : http://agritek.unmermadiun.ac.id/index.php/agritek

Studi In vitro telah menunjukkan bahwa bawang putih memiliki aktivitas melawan banyak bakteri gram negatif dan bakteri gram positif. Beberapa bakteri yang telah diuji sensitivitasnya terhadap bawang putih antara lain ialah Staphylococcus epidermidis. Kemampuan antibakteri ini diyakini dikarenakan adanya zat aktif Allicin,minyak atsiri, Flavonoid dalam bawang putih. Perbedaan daya ekstrak bawang putih dengan berbagai konsentrasi terhadap Staphylococcus epidermidis dapat dilihat dari data penelitian perhitungan statistik Kruskal-Wallis yang kemudian dilanjutkan dengan Post Hoc Test menggunakan uji Mann-Whitney untuk mengetahui data mana yang berbeda. Berdasarkan hasil uji statistik didapatkan hasil perbandingan kelompok chloramphenicol dengan kelompok aquadest, ekstrak bawang putih konsentrasi 50\%, 25\%, 12,5\% memiliki perbedaan bermakna dengan maksud khasiatnya tidak seefektif chloramphenicol. Pada kelompok aquadest dibandingkan dengan kelompok ekstrak bawang putih dengan konsentrasi 25\%, 12,5\%, 6,25\% memiliki perbedaan yang bermakna, sehingga pada kadar tersebut keefektifannya tidak sama dengan aquadest. Pada kelompok ekstrak bawang putih dengan konsentrasi $100 \%$ dibandingkan dengan konsentrasi $50 \%, 25 \%, 12,5 \%, 6,25 \%$ memiliki perbedaan yang bermakna, sehingga pada konsentrasi $100 \%$ lebih efektif dibanding konsentrasi lainnya namun tidak seefektif chloramphenicol. Pada kelompok ekstrak bawang putih pada konsentrasi 50\% memiliki perbedaan bermakna dibanding pada konsentrasi 25\%, 12,5\%, 6,25\% sehingga pada konsentrasi tersebut memiliki keefektifan yang lebih baik. Pada kelompok ekstrak bawang putih berkonsentrasi $25 \%$ memiliki perbedaan bermakna dengan konsentrasi $12,5 \%$ dan 6,25\%. Dan terakhir pada kelompok ekstrak bawang putih konsentrasi $12,5 \%$ memiliki perbedaan bermakna dengan konsentrasi ekstrak bawang putih 6,25\%. Data tersebut dikatakan bermakna terdapat perbedaan apabila $\mathrm{p}<0,05$.

Dari data ada statistik yang didapatkan, disimpulkan H0 ditolak karena perbedaan (minimal sepasang) dari 7 kelompok perlakuan. Terbentuknya diameter daya hambat pertumbuhan terhadap Staphylococus epidermidis yang berarti ekstrak bawang putih (Allium sativum L.) memiliki antibakteri dalam menghambat pertumbuhan Staphylococcus epidermidis.

\section{KESIMPULAN}

Terdapat perbedaanreratayang signfikan antara pemberian ekstrak bawang putih dalam menghambat pertumbuhan Staphylococcus epidermidis dengan metode difusi dalam konsentrasi $100 \%, 50 \%, 25 \%, 12,5 \%, 6,25 \%$. Semakin besar konsentrasi ekstrak bawang putih yang diberikan, semakin besar pula efek antibakteri dalam bentuk diameter zona hambat terhadap pertumbuhan bakteri Staphylococcus epidermidis.

\section{VI.DAFTAR PUSTAKA}

Darmadi. Infeksi Nosokomial Problematika dan Pengendaliannya. Jakarta: Penerbit Salemba Medika; 2008. p. 170.

Brooks AGF, Carroll KC, Butel JS, Morse SA. Jawetz, Melnick \& Adelberg's, Medical Microbiology 24 th Edition. 2007;7(3):273-5.

Raafat D, Sahl HG. Chitosan and its antimicrobial potential - A critical literature survey. Microb Biotechnol. 2009;2(2 SPEC. ISS.):186-201.

Organization WH. Antimicrobial resistance: Global Health Report on Surveillance. Bull World Health Organ [Internet]. 2014;1-256.

Yang C, Chhabra S, Hong J, Smith T. Recent Advances on the Nutritional Effects Associated with the Use of Garlic as a Supplement Historical Perspective on the Use of Garlic. J Nutr. 2001;131:951-4.

Kemper KJ. Garlic ( Allium sativum ). Longwood Herb Task Force. 2000;1-49.

R.R. C, P. W. Antibacterial activity of a new, stable, aqueous extract of allicin against methicillin-resistant Staphylococcus aureus. Br J Biomed Sci [Internet]. 2004;61(2):71-4.

r Rijeka, Croatia 